\title{
Algorithm of Energy Efficiency Improvement for Intelligent Devices in Railway Transport
}

\author{
Anna Beinaroviča (Ph.D. student, Riga Technical University), Mihails Gorobecs (Assistant Professor, \\ Riga Technical University), Anatolijs L,evčenkovs (Professor, Riga Technical University)
}

\begin{abstract}
The present paper deals with the use of systems and devices with artificial intelligence in the motor vehicle driving. The main objective of transport operations is a transportation planning with minimum energy consumption. There are various methods for energy saving, and the paper discusses one of them proper planning of transport operations. To gain proper planning it is necessary to involve the system and devices with artificial intelligence. They will display possible developments in the choice of one or another transport plan. Consequently, it can be supposed how much the plan is effective against the spent energy. The intelligent device considered in this paper consists of an algorithm, a database, and the internet for the connection to other intelligent devices. The main task of the target function is to minimize the total downtime at intermediate stations. A specific unique PHPbased computer model was created. It uses the MySQL database for simulation data storage and processing. Conclusions based on the experiments were made. The experiments showed that after optimization, a train can pass intermediate stations without making multiple stops breaking and accelerating, which leads to decreased energy consumption.
\end{abstract}

Keywords - Algorithm; Artificial intelligence; Database; Energy consumption; Intelligent systems; Logic; Mathematical model; Optimization; Process planning.

\section{INTRODUCTION}

One of the main objectives of transport operations is a transportation process that spends the minimum amount of resources and brings the best results or profits.

The labor costs in man-hours, the number and type of vehicles, and the energy spent on transportation can be mentioned as the main resources.

This paper deals with energy consumption in railway transport operation process and the possibility for its minimization [1].

\section{PROBLEM FoRMULATION}

As the study of the problem, it was taken a transport operations wrong planning, whereupon the energy consumption increases and efficiency decreases.

In a diesel-electric locomotive, the diesel engine drives either an electrical DC generator (generally, less than 3000 horsepower $(2200 \mathrm{~kW})$ net for traction), or an electrical AC alternator-rectifier (generally, 3000 horsepower $(2200 \mathrm{~kW})$ net or more for traction), the output of which provides the power to the traction motors that drive the locomotive (Fig. 1). There is no mechanical connection between the diesel engine and the wheels [2].
To provide changes in speed and traction force, it is necessary to regulate the current of the traction motor and the traction generator voltage.

The connection between the useful power, voltage and the current of the traction generator:

$$
P_{\mathrm{g}}=\eta_{\mathrm{g}} N_{d}=U_{\mathrm{g}} I_{\mathrm{g}},
$$

where

$P_{\mathrm{g}}$ - useful power;

$I_{\mathrm{g}}$ - current of the traction generator;

$U_{\mathrm{g}}-$ voltage.

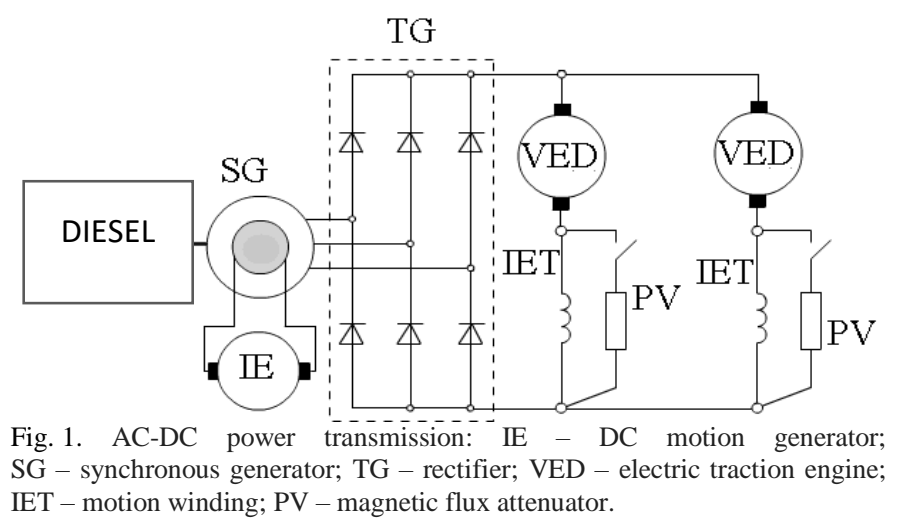

The locomotive's control system is designed so that the main generator electrical power output is matched to any given engine speed. Given the innate characteristics of traction motors, as well as the way in which the motors are connected to the main generator, the generator will produce high current and low voltage at low locomotive speeds, gradually changing to low current and high voltage as the locomotive accelerates. Therefore, the net power produced by the locomotive will remain constant for any given throttle setting (Fig. 2) [2], [3].

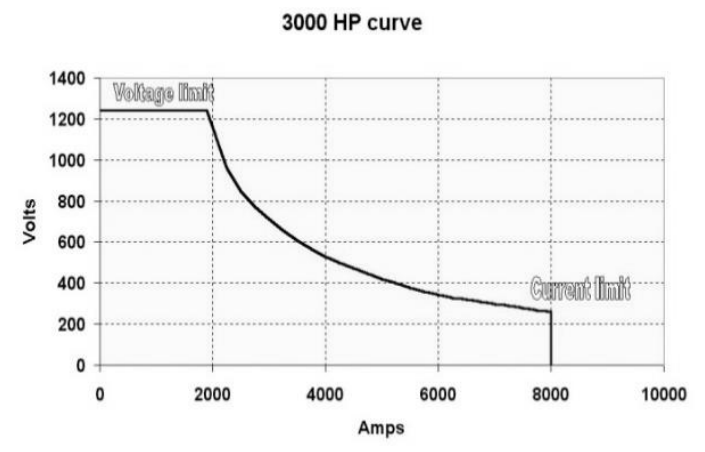

Fig. 2. Typical main generator constant power curve at "notch 8 ". 
It is important to plan the work so that the locomotive does not idle with a working engine.

\section{SYSTEM STRUCTURE}

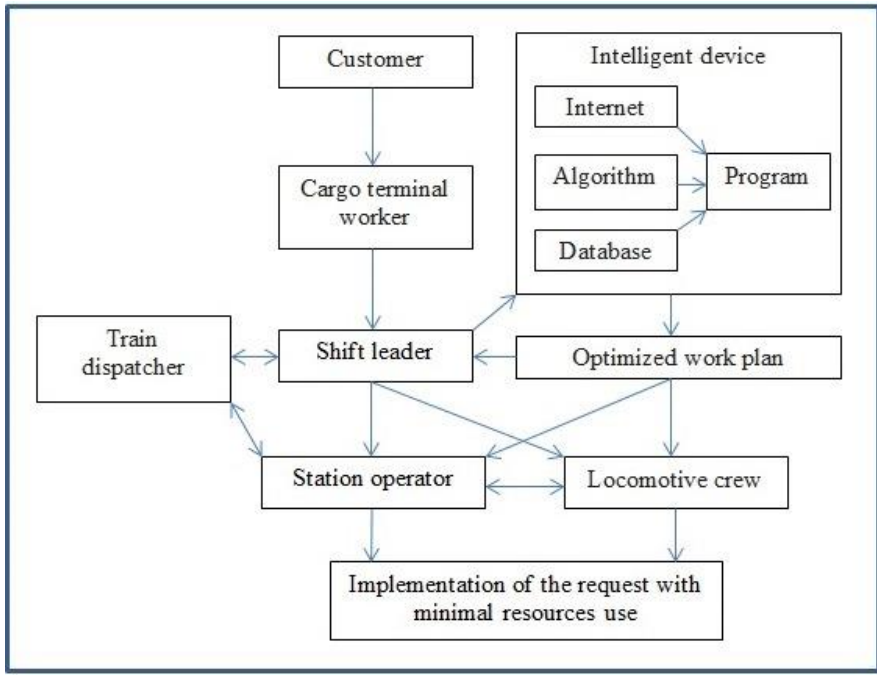

Fig. 3. System structure scheme.

Fig. 3 displays the dependence of transportation organization. In Fig. 3, Customer - the customer who uses the services of railway;

Cargo terminal worker - the worker who is responsible for receiving and delivering the cargo;

Shift leader - the man who is planning the work on a terminal:

Train dispatcher - the shift leader on a junction;

Station operator - the shift leader on a station or park;

Locomotive crew - a machinist, an assistant of the machinist, a train conductor [4];

Intelligent device - the device which analyzes the work plan and offers an optimized route;

Optimized plan - an optimized plan of route, according to which a smaller amount of stops in passing stations is made and less energy is taken [5].

The structure of the system shows how individual units interact in the cargo terminal transport operation process.

At present, the optimized work plan is made by shift leader and locomotive crew. According to the human factor, the chosen work plan can be suboptimal and may lead to increased energy outlays while making transport operations. An intelligent device can coordinate a proper plan selection.

\section{TRANSPORTATION OPERATIONS PLANNING}

Planning of the transport operations at the cargo terminal "Tornakalns" was the framework for the experiment. As only irregular transportations are carried out on the analysed terminal, the train does not have a timetable. Free time on the running line, which remains after all scheduled passenger and freight trains, is used [6], [7].
Target function:

$$
T=\sum_{i=2}^{n}\left(t_{i}^{\mathrm{s}}+t_{i-1}^{\mathrm{b}}\right) \rightarrow \min ,
$$

where

$t_{i}^{\mathrm{s}}$ - time of departure from the station;

$t_{i-1}^{\mathrm{b}}$ - time of arrival to the station.

Target function can be explained by the time axis,

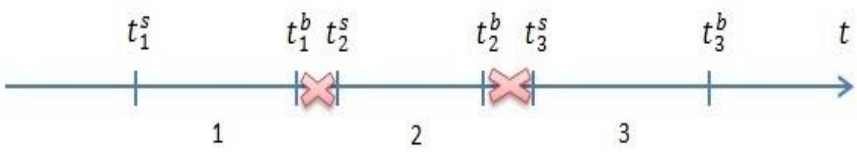

Fig. 4. Explanation of the target function.

where:

1 - first span (Tornakalns-Zasulauks); 2 - second span (Zasulauks-Lacupe); 3 - third span (Lacupe-Bolderaja); $t_{1}^{S}-$ train departure time from the first park (Tornakalns); $t_{1}^{b}-$ train arrival time at the nearby park (Zasulauks); $t_{2}^{S}$ - train departure time from the second park (Zasulauks); $t_{2}^{b}$ - train arrival time at the third nearby park (Lacupe); $t_{3}^{S}$ - train departure time from the third park (Lacupe); $t_{3}^{b}$ - train arrival time at a terminal station (Bolderaja).

The main task of the target function is to reduce downtime at intermediate stations to zero [8]:

$$
T=\left(t_{2}^{\mathrm{s}}-t_{1}^{\mathrm{b}}\right)+\left(t_{3}^{\mathrm{s}}-t_{2}^{\mathrm{b}}\right) \rightarrow \min .
$$

This will lead to non-stop through the intermediate stadions, and energy consumption will be minimized [9].

The specially developed software is offered as the system of planning irregular transport operations, which makes a selection from the database, makes calculations, and records the obtained results in a database.

The relation database is made in MYSQL DBMS. The database is easy to use, because the information input into it is easily changeable. If conditions are changed, there is no need to rewrite the entire code.

The database called "ldz" contains six tables: the table of the departure and arrival points, the table of the spans between departure and arrival points, two tables with passenger trains, the table with freight trains, and the table with saved results or saved trains.

Each post, park, or station in „Station/Parks/Posts" table is marked with a unique number ID.

TABLE I

STATIONS/PARKS/POSTS

\begin{tabular}{|c|c|}
\hline ID & Name of the post/park/station \\
\hline 1 & Post of the $8^{\text {th }} \mathrm{km}$ \\
\hline 2 & Tornakalns park \\
\hline 3 & Zasulauks park \\
\hline 4 & Lacupe park \\
\hline 5 & Bolderaja station \\
\hline
\end{tabular}


TABLE II

SPANS

\begin{tabular}{|c|c|c|}
\hline ID & Departure station ID & Arrival station ID \\
\hline 1 & 1 & 2 \\
\hline 2 & 2 & 3 \\
\hline 3 & 3 & 2 \\
\hline 4 & 3 & 4 \\
\hline 5 & 4 & 5 \\
\hline
\end{tabular}

Each span is marked with a unique number ID.

The span "Tornakalns park - Zasulauks park" is a two-way span, that is why it has two IDs (2 and 3), according to the direction of movement.

TABLE III

PASSENGER TRAINS RUNNING EVERY DAY* [10]

\begin{tabular}{|c|c|c|c|c|}
\hline ID & $\begin{array}{c}\text { Spans } \\
\text { ID }\end{array}$ & $\begin{array}{c}\text { Trains } \\
\text { number }\end{array}$ & Departure time & Arrival time \\
\hline 1 & 1 & 6702 & $05: 40: 00$ & $06: 01: 00$ \\
\hline
\end{tabular}

TABLE IV

PASSENGER Trains RUNNING DEPENDING ON THE DAY OF THE WEEK ${ }^{*}$ [10]

\begin{tabular}{|c|c|c|c|c|c|c|c|c|c|c|c|}
\hline$\theta$ & 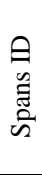 & 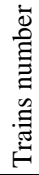 & 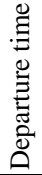 & 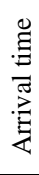 & $\stackrel{\text { Z }}{\stackrel{2}{z}}$ & 罗 & $\frac{9}{3}$ & $\underset{ت}{\stackrel{\Xi}{ت}}$ & $\overrightarrow{\underline{x}}$ & 离 & Z \\
\hline 1 & 1 & 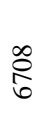 & 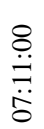 & $\begin{array}{l}\stackrel{8}{\dot{m}} \\
\text { r̊ } \\
\text { ஸे }\end{array}$ & 1 & 1 & 1 & 1 & 1 & 0 & 0 \\
\hline 2 & 3 & $\stackrel{\infty}{\stackrel{\rho}{~}}$ & 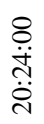 & 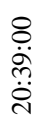 & 0 & 0 & 0 & 0 & 0 & 0 & 1 \\
\hline
\end{tabular}

The uniqueness of table IV is the possibility of finding a particular train by using clear logic. Number 1 means that train is running on this day. Number 0 means that train isn't running on this weekday.

TABLE V

SCHEDULED FREIGHT TRAINS ${ }^{*}[10]$

\begin{tabular}{|c|c|c|c|c|}
\hline ID & Spans ID & $\begin{array}{c}\text { Trains } \\
\text { number }\end{array}$ & Departure time & Arrival time \\
\hline 1 & 3 & 3202 & $01: 06: 00$ & $01: 23: 00$ \\
\hline
\end{tabular}

TABLE VI

SAVED TRAINS*

\begin{tabular}{|c|c|c|c|c|}
\hline ID & Spans ID & $\begin{array}{c}\text { Departure } \\
\text { time }\end{array}$ & Arrival time & Date \\
\hline 1 & 2 & $08: 35: 00$ & $08: 55: 00$ & 1463583998 \\
\hline
\end{tabular}

The uniqueness of Table VI is the "Date" column, where the departure date is saved in UNIX format.

The Table VI includes data. The algorithm processes the information from the database and complements it.

The mathematical model for intelligent devices for route planning is represented by the following definitions:

- set of stations $-\mathrm{P}=\left(\mathrm{P}_{1}, \mathrm{P}_{2}, \ldots, \mathrm{P}_{n}\right)$;

- set of spans $-\mathrm{PP}=\left(\mathrm{P}_{1} \mathrm{P}_{2}, \mathrm{P}_{2} \mathrm{P}_{3}, \ldots, \mathrm{P}_{n-1} \mathrm{P}_{n}\right)$

- set of passenger trains - $\mathrm{PT}=\left(\mathrm{PT}_{1}, \mathrm{PT}_{2}, \ldots, \mathrm{PT}_{n}\right)$;

- set of freight trains $-\mathrm{FT}=\left(\mathrm{FT}_{1}, \mathrm{FT}_{2}, \ldots, \mathrm{FT}_{n}\right)$;

- schedule $A=\sum_{i}^{p}=\left(t_{1}, t_{2}, \ldots, t_{j}, \ldots, t_{m}\right)$ - time moments of the arrival of $j$-th vehicle if $i$-th stop is included in the vehicles route [11], [12].

- schedule $D=\sum_{i}^{p}=\left(t_{1}, t_{2}, \ldots, t_{j}, \ldots, t_{m}\right)$ - time moments of the departure of $j$-th vehicle if $i$-th stop is included in the vehicles route [11], [12].

\section{The Algorithm}

The steps of the algorithm for HMI (human-machine interface) are developed in Latvian, thus adopted for local usage.

STEP 1. Connecting to the server and database.

STEP 2. Departure station 'from_place' and destination station 'to_place', time of departure 'nlaiks', availability of public holiday 'svetki' (holidays) request, the buttons "Pārbaudīt" (Check) output.

STEP 3. Data checking.

STEP 4. Storing of the set parameters 'svetki' (holidays), 'nlaiks' (time), 'from_place', 'to_place'.

STEP 5. Spans ID finding SELECT * FROM 'posmi` (spans).

STEP 6. Departure station names \$row_stac_1 and destination station names \$row_stac_2 output. Spans ID \$row['id'] output.

STEP 7. Freight trains number 'kvnum' and trains following time 'laiksno' (time from), 'laikslidz' (time to) output.

STEP 8. Additional limitation "Slēgts" (Closed) output.

STEP 9. Calculation of the remaining spans included in the route \$_POST['from_place'].

STEP 10. The buttons "Turpināt" (Continue) output. It clicking check.

STEP 11. The direction of movement checking.

STEP 12. Spans ID finding.

STEP 13. Departure station names \$row_stac_1 and destination station names \$row_stac_2 output.

STEP 14. Unlimited array \$arr create.

STEP 15. Noted additional limitation entering into an \$arr array.

STEP 16. Passenger trains (that run every day) entering into an \$arr array.

STEP 17. Passenger trains (that run depending on the day of the week) entering into an \$arr array.

STEP 18. Saved trains entering into an \$arr array.

STEP 19. Marked freight trains entering into an \$arr array.

${ }^{*}$ Fragments of the full tables. 
STEP 20. Sorting an \$arr array.

STEP 21. Setting a time interval from \$date_now to \$date_p.

STEP 22. Intervals entered in an array separation on the beginning of time interval 'laiksno' (time from) and the end of the time interval 'laikslidz' (time to).

STEP 23. The condition of the closing of the day, if before the end of the day is no more busy intervals.

STEP 24. The calculated "crossing station" interval entering.

STEP 25. The condition of the coincidence of the free interval with a noted additional limitation interval.

STEP 26. Calculation of the free intervals and saving in $\$$ memory variable.

STEP 27. Time of departure calculation and saving in \$first variable.

STEP 28. Time of arrival calculation and saving in \$second variable.

STEP 29. Free intervals \$first.'-'.\$second entering into an \$arr array.

STEP 30. All free intervals from an \$arr array output.

STEP 31. Departure time 'nlaiks' output.

STEP 32. Downtime \$ dd (on passing station) calculation and output.

STEP 33. From the first station recommended departure time \$next_posms_explode232 output.

STEP 34. "Atcelt" (Cancel) and "Saglabāt" (Save) buttons output.

STEP 35. Entering data in a request. The new following a route time calculation, considering recommended departure time.

STEP 36. Results saving in the database.

STEP 37. Return to the STEP 1. [13]-[15]

\section{EXPERIMENT}

The first request was entered (Fig. 5).

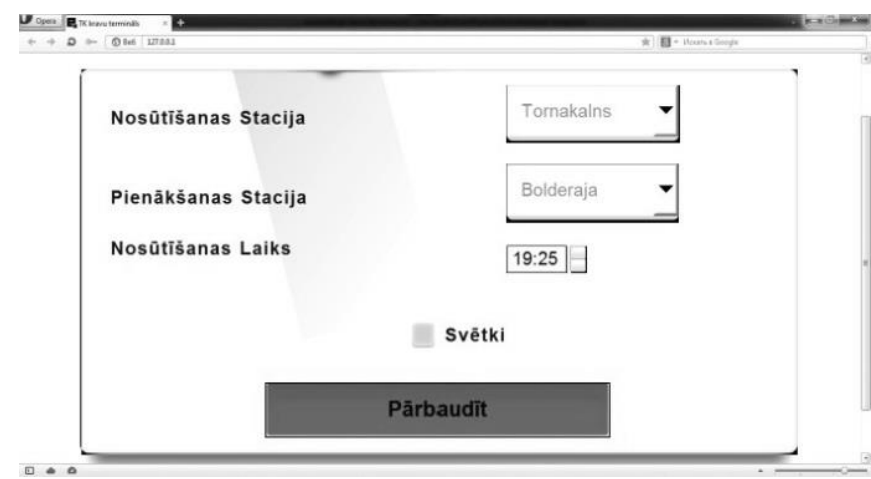

Fig. 5. First request.
Departure station - Tornakalns; destination station Bolderaja; desired departure time - 19:25; no holidays.

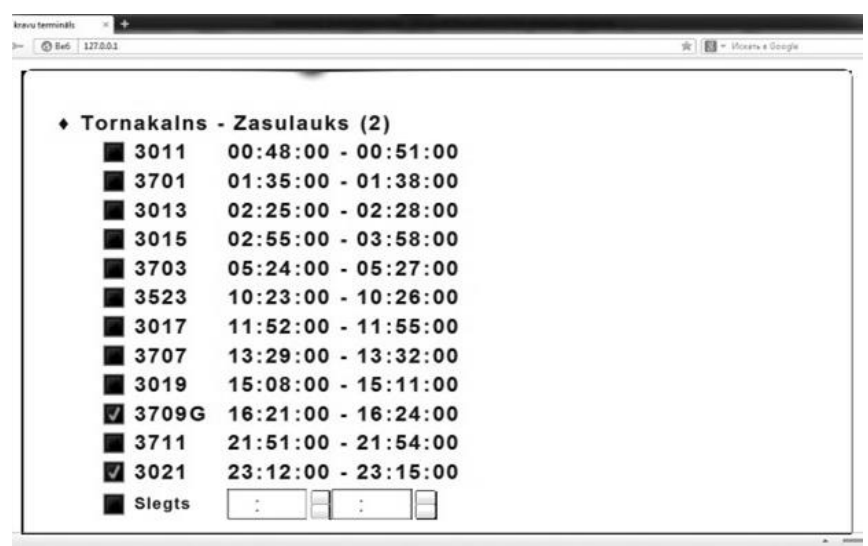

Fig. 6. Second request.

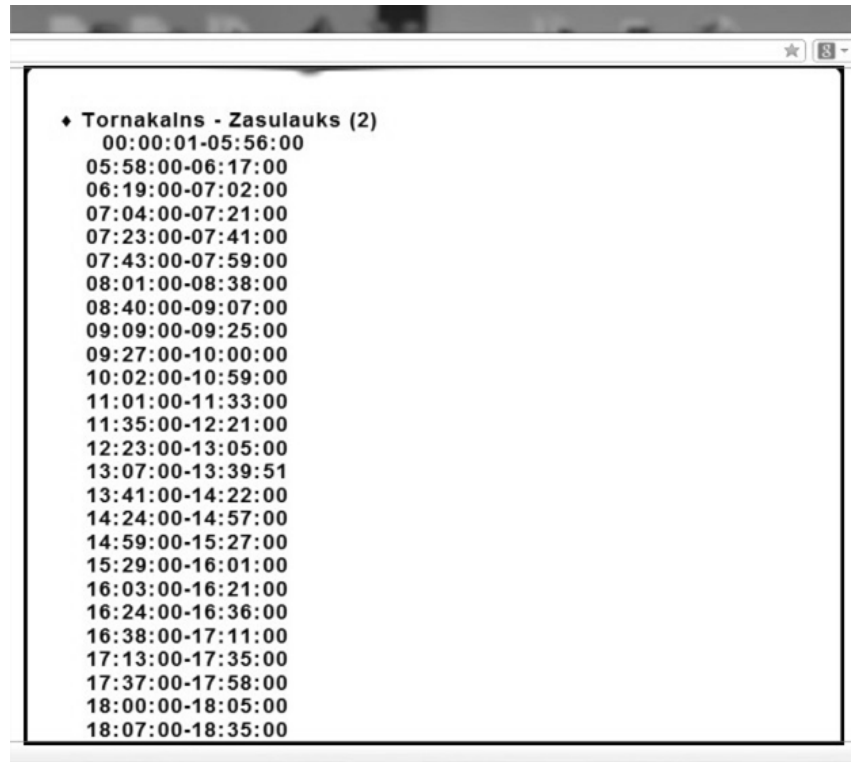

Fig. 7. All available intervals.

The software searches for the scheduled freight trains for the selected route, and offers to mark them (Fig. 6).

Upon completion of both requests, the result is displayed.

The result is divided into two parts: the first part - display of all intervals available on the running line during the day (Fig. 7); the second part - calculated time on the running line before the optimization (Fig. 8). 


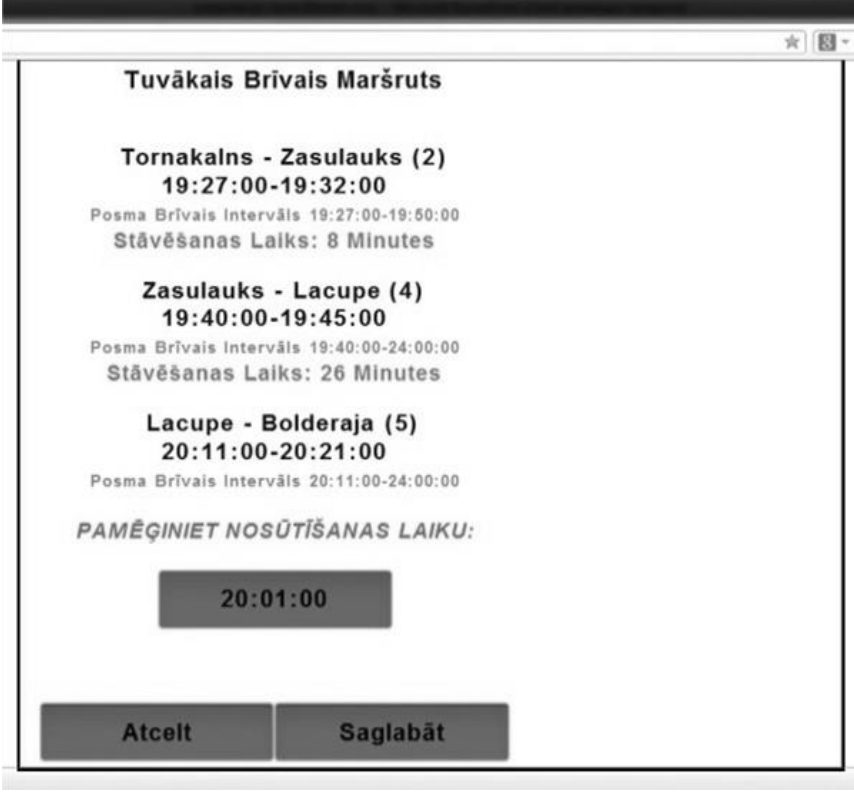

Fig. 8. Result before the optimization.

Upon the receipt of the recommended time, the software recalculates the result by using the stored requests and changing only the desired departure time: "from 19:25 to 20:01". We get the result after optimization (Fig. 9).

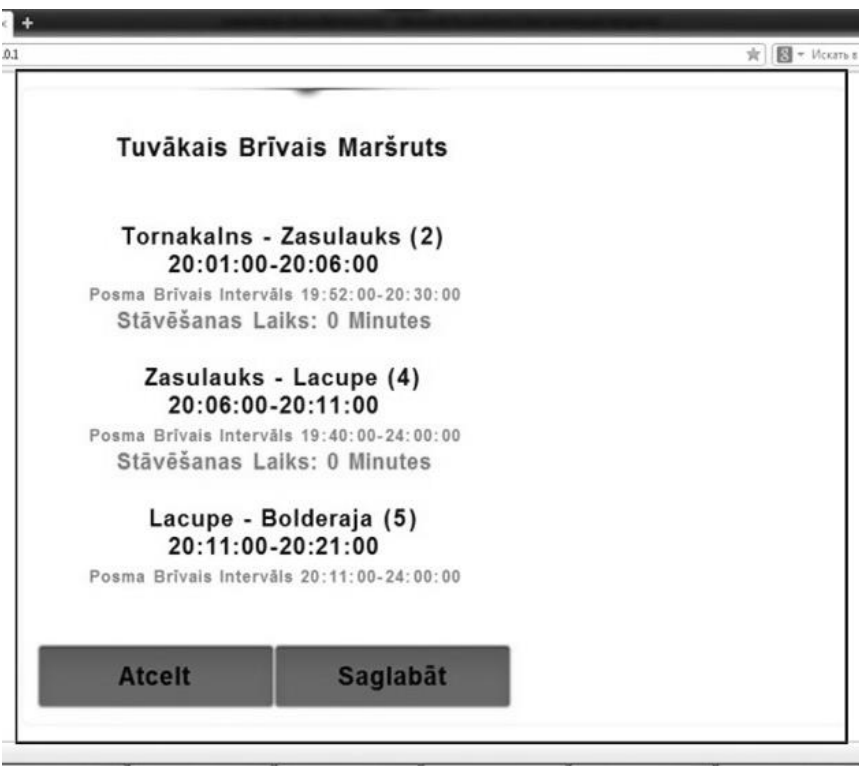

Fig. 9. Result after the optimization.

After optimization, the time of standing at the stations is 0 minutes.

When the optimized result is obtained, the user can save the result in the database and take into account this time as busy time for future transportation planning.

The comparison of the two results received in the experiment is displayed in Table VII.

Before optimization, the Tornakalns cargo terminal train is sent from Tornakalns park 2 minutes later than the preferred departure time: at 19:27. The train arrives at Zasulauks park and stands there for 8 minutes; then it is sent to the Lacupe park. In the Lacupe park, the train again makes a stop and stands for 26 minutes before being sent to Bolderaja station. The software offer before the optimization: to send the train from the Tornakalns park at 19:27 (2 minutes later), make two intermediate stops, with the total downtime of 34 minutes.

TABLE VII

COMPARISON OF THE RESULTS

\begin{tabular}{|c|c|c|c|}
\hline Operation & Park/station & $\begin{array}{c}\text { Before } \\
\text { optimization }\end{array}$ & $\begin{array}{c}\text { After } \\
\text { optimization }\end{array}$ \\
\hline Departure & Tornakalns & At 19:27 & At 20:01 \\
\hline $\begin{array}{c}\text { Departure time shift } \\
\text { from the desired time } \\
\text { 19:25 }\end{array}$ & Tornakalns & 2 min & 36 min \\
\hline Arrival & Zasulauks & At 19:32 & At 20:06 \\
\hline Downtime & Zasulauks & $\mathbf{8}$ min & 0 min \\
\hline Departure & Zasulauks & At 19:40 & At 20:06 \\
\hline Arrival & Lacupe & At 19:45 & At 20:11 \\
\hline Downtime & Lacupe & $\mathbf{2 6 ~ m i n}$ & 0 min \\
\hline Departure & Lacupe & At 20:11 & At 20:11 \\
\hline Arrival & Bolderaja & At 20:21 & At 20:21 \\
\hline \multicolumn{2}{|c|}{ Downtime sum } & $\mathbf{3 4 ~ m i n}$ & 0 min \\
\hline
\end{tabular}

After optimization, the Tornakalns cargo terminal train is sent from Tornakalns park 36 minutes later than the preferred departure time: at 20:01. It is sent through the intermediate stations without stopping and downtime and arrives at the Bolderaja station at the same time as before the optimization: at 20:21

Comparison of both results suggests that the first result is offered to the closest time of departure from the first park, but it may be suboptimal. But in the second result, the number of intermediate stops and the downtime is minimized by using a later departure time from Tornakalns park.

Thus, the developed algorithm helps the person in decisionmaking on the time and route of the train departure so that only one train can be located on the running line without any intermediate block signals.

\section{CONCLUSION}

Control systems and devices with artificial intelligence can greatly facilitate driving the transport.

The experiment presents the system of planning of irregular transportations in railway transport. This system optimizes the traffic on a given route, while taking into account the holding time of running lines by other trains. The experiment shows that two stops are performed before the optimization at the passing stations, and the total time of downtime is 34 minutes. After optimization, the downtime is minimized and reduced to zero, which minimizes the amount of consumed energy. 
The study proved that it is important to upgrade the equipment of locomotives, to reduce the amount of energy consumed, as well as to plan correctly. The intelligent systems that are designed on an algorithm process the information from the database and can greatly simplify the task of planning. These systems can also improve the efficiency for transport, minimizing the energy consumption.

\section{REFERENCES}

[1] C. Sicre, P. Cucala, A. Fernández, J. A. Jiménez, I. Ribera and A. Serrano, "A method to optimise train energy consumption combining manual energyefficient driving and scheduling," WIT Trans. on The Built Environment, pp. 549-560, 2010. https://doi.org/10.2495/CR100511

[2] I. Dincer, J. Hogerwaard and C. Zamfirescu, Clean Rail Transportation Options (Green Energy and Technology Series), Switzerland: Springer International Publishing, 2016. https://doi.org/10.1007/978-3-319-21726-0

[3] Railway Technical Web Pages, Electronic Power for Trains. [Online]. Available: http://www.railway-technical.com/tract-02.shtml.

[4] J. Smirnovs, P. Balckars, D. Sergejevs, T. Altbergs and V. Greckis, Dzelzcel̦i. Vispārīgais kurss (Railways. General Course), Riga, Latvia: VAS “Latvijas Dzelzcel̦šs”, 1996. 279 p.

[5] I. Alps, "Modelling of Intelligent Electrical Transport Control Systems Scheduling Problems in the Unforseen Cases," Doctoral Thesis, Faculty of Power and Elect. Eng., Riga Technical University, 2012, 155 p.

[6] Ministru kabinets. (2010 Aug. 3). Dzelzceḷa Tehniskās Ekspluatācijas Noteikumi. [Online].

Available: http://likumi.lv/doc.php?id=214699\&cs=f521ff1e

[7] R. W. Conway, W. L. Maxwell and L. W. Miller, Theory of Scheduling, Mineola, New York: Dover Publications, Inc., 2003, 304 p.

[8] H.-S. Hwang, "Control strategy for optimal compromise between trip time and energy consumption in a high-speed railway," IEEE Trans. on Systems, Man, and Cybernetics - Part A: Systems and Humans, vol. 28, no. 6, pp. 791-802, Nov. 1998. https://doi.org/10.1109/3468.725350

[9] G. N. Brooks and C. R. White, "An Algorithm for Finding Optimal or Near Optimal Solutions to the Production Scheduling Problem,' J. Industrial Eng., vol. 16, 1965.

[10] Information about Latvian railway. [Online]. Available: interior site https://ldzintranet.int.ldz.lv/

[11] VAS „LDz”, Freight trains schedule, Riga, Latvia, 2013. 81 p.

[12] M. Gorobecs, I. Alps and A. Levčenkovs, "Mathematical Formulation of Public Electric Transport Scheduling Task for Artificial Immune Systems," in Proc. of RTU 50th Int. Scientific Conf. "Power and Electrical Eng. ", Latvia, Riga, 2009, pp. 159-164.

[13] CyberForum, Forum of programmers and system administrators. [Online]. Available: http://www.cyberforum.ru

[14] CakePHP 2.x Cookbook, Models. [Online]. Available: http://book.cakephp.org/2.0/en/models.htm

[15] Tutorialspoint, MySQL PHP Syntax. [Online]. Available: https://www.tutorialspoint.com/mysql/mysql-php-syntax.htm
Anna Beinaroviča is a $\mathrm{Ph} . \mathrm{D}$. student of the Institute of Industrial Electronics and Electrical Engineering of Riga Technical University. She received the degrees of B.Sc. and M.Sc. in railway transport from Riga Technical University in 2014 and 2016, respectively. In 2010, she participated in the scientific conference for young researches "Research Innovations Fundamentals 2010" in Lithuania, Klaipeda. In 2016, she participated in the scientific conference RTUCON 2016 in Riga.

Address: Āzenes iela 12-1, Riga, LV-1048, Latvia.

Mihails Gorobecs received the Dr. sc. ing. degree in 2008. At present, he is an Assistant Professor and the leading researcher of the Institute of Industrial Electronics and Electrical Engineering at Riga Technical University. The results of his research have been published in various international scientific proceedings in the fields of adaptive control, neural networks, genetic algorithms, modelling and simulation of dynamic processes. He is a leader of various national projects and international projects. $\mathrm{M}$. Gorobecs is an author of many study books and patented inventions.

Address: Āzenes iela 12-1, Riga, LV-1048, Latvia.

Anatolijs Levčenkovs, Dr. sc. ing., Professor at the Institute of Industrial Electronics and Electrical Engineering and the Institute of Railway Transport of Riga Technical University. He received the diploma of an engineer in electrical engineering in 1969, and the Dr. sc. ing. degree in 1978. His fields of interests are optimization theory, group decision support systems, negotiation support systems, scheduling, logistics, intelligent transport systems, evolutionary algorithms for embedded systems. A. Levčenkovs has been leading various national and international projects, and he is an author of many patents, books, and publications.

Address: Āzenes iela 12-1, Riga, LV-1048, Latvia. 